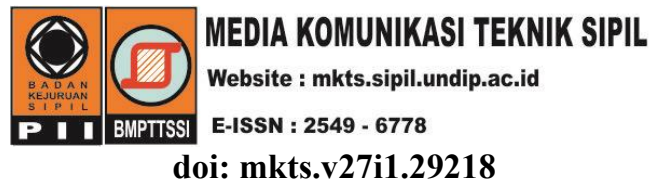

\title{
The Use of Ground Motion Parameters to Identify the Liquefaction during a Strong Earthquake in Northern Thailand
}

\author{
Lindung Zalbuin Mase \\ Civil Engineering, Faculty of Engineering, University of Bengkulu, Bengkulu, Indonesia \\ lmase@unib.ac.id
}

Received: 24 Maret 2020 Revised: 23 Juli 2021 Accepted: 28 Juli 2021

\begin{abstract}
Abstrak
Naskah ini menyajikan analisis respon situs untuk mensimulasikan fenomena likuifaksi selama Gempa Tarlay 2011 di Thailand Utara. Data investigasi lapangan dan pengukuran geofisik pada tujuh lokasi di Thailand Utara, dikumpulkan. Model multisprings element diterapkan pada analisis respon seismic dalam kerangka kerja metode elemen hingga. Beberapa parameter seperti percepatan maksimum gempa, kecepatan maksimum gempa, faktor amplifikasi, dan rasio peningkatan air pori diamati. Selanjutnya, korelasi dari parameter tersebut dirancang untuk memperkirakan potensi likuifaksi yang direpresentasikan oleh rasio peningkatan air pori. Hasil penelitian memperlihatkan bahwa rasio tekanan air pori memiliki hubungan kecendrungan yang relative baik, khususnya terhadap faktor amplifikasi, rasio kecepatan dan percepatan, dan faktor aman terhadap likuifaksi. Hasil penelitian ini dapat pula digunakan untuk keperluan praktis dalam memprediksi potensi likuifaksi di Thailand Utara.
\end{abstract}

Kata kunci: Investigasi lapangan, analisis respon tanah, likuifaksi, rasio peningkatan tekanan air pori

\begin{abstract}
This paper presents a ground response analysis to simulate the liquefaction phenomenon during the 2011 Tarlay Earthquake in northern Thailand. The site investigation data and geophysical measurements on seven sites in northern Thailand were collected. The multi-springs element model was implemented in finite element ground response analysis. Several parameters, such as peak ground acceleration, peak ground velocity, amplification factor, excess pore pressure ratio, were observed. Furthermore, the correlation from the ground motion parameters was generated to estimate liquefaction potential, which was represented by excess pore pressure ratio. The result showed that the excess pore pressure ratio was relatively well correlated with several ground parameters, such as amplification factor, velocity-acceleration ratio, and factor of safety against liquefaction. The results could be also used for the engineering practice in predicting liquefaction potential in Northern Thailand.
\end{abstract}

Keywords: Site investigation, ground response analysis, liquefaction, excess pore pressure ratio

\section{Introduction}

It has been known that the strong earthquake could result in the intensive damage to the soil and structural building. The damage, such as liquefaction, is one of the geotechnical phenomena following the earthquake shaking. Several earthquake events, such as the 1995 Kobe Earthquake in Japan (Mase et al., 2019), the 2006 Jogja Earthquake (Mase, 2017b) in Indonesia, the 2007 Bengkulu-Mentawai Earthquake (Mase, 2017a; Mase, 2018) in Indonesia, and the 2011
Tarlay Earthquake (Mase et al., 2018a) in Thailand, had triggered liquefactions. The liquefaction phenomenon could be understood by two aspects, i.e. the earthquake quantity and the geological condition. The geological conditions, such as the domination of saturated sandy soils with loose to medium density, could be some governing factors of liquefaction. The earthquake parameters, such as magnitude of earthquake and peak ground acceleration (PGA) could also significantly influence the damage intensity of liquefaction (Idriss \& Boulanger, 2006). 
Mase (2020) stated that minimum magnitude of $M_{w}$ 5 and PGA of $0.1 \mathrm{~g}$ are required to trigger liquefaction on sandy soil sites. Those criteria had been used as the preliminary aspects in analysis of soil liquefaction (Mase et al., 2018a). A study of liquefaction potential is normally initiated by empirical analysis. The main concept of empirical analysis is to compare cyclic resistance ratio $(C R R)$ and cyclic stress ratio $(C S R)$. CRR reflects the availability of soil resistance against earthquake loading. Site investigation data, such as standard penetration test (SPT) and cone penetration test (CPT) are therefore used in analysis. CSR reflects the released earthquake energy which could trigger liquefaction. The earthquake aspect, such as maximum peak ground acceleration $\left(A_{\max }\right)$, is used in analysis. Other parameters, such as ratio between $A_{\max }$ and maximum peak ground velocity $\left(V_{\max }\right)$ and amplification factor $(A F)$ has not been still fully considered in determining the liquefaction potential.

This paper presents ground motion analysis and liquefaction potential. The earthquake event called Tarlay Earthquake with magnitude of $\mathrm{M}_{\mathrm{w}} 6.8$ are studied. Analysis of liquefaction potential using multisprings element models (Iai et al., 1992) was performed to simulate liquefaction. Liquefaction parameters called excess pore pressure ratio $\left(r_{u}\right)$ and Factor of Safety $(F S)$ are observed. Ground motion parameters including $A_{\max }, V_{\max }$, and $A F$ are also studied. The simple regression analysis is performed to observe the tendency of ground motion parameters to liquefaction potential. This study proposes the empirical model to estimate liquefaction susceptibility in Northern Thailand.

\section{Method}

Soil liquefaction during earthquake can be categorised as one of special topics in geotechnical engineering. In engineering practice, the empirical analysis is still the most selected method to determine the liquefaction potential. The empirical analysis is conducted by analysis the site investigation data, such as CPT and SPT. The main concept of this method is to compare $C R R$ and $C S R$ to obtain $F S$ against liquefaction (Idriss \& Boulanger, 2006). FS can be also used to estimate excess pore pressure ratio $\left(r_{u}\right)$. Yegian \& Vitteli (1981) proposed the correlation between $F S$ and $r_{u}$ (Equation 2). In Equations 1 and 2, CSR is cyclic stress ratio (no dimension), $r_{d}$ is depth reduction factor (no dimension), MSF is magnitude scaling factor (no dimension), $K_{\sigma}$ is overburden correction factor (no dimension) (Idriss \& Boulanger, 2006), $A_{\max }$ is maximum peak ground acceleration $\left(\mathrm{m} / \mathrm{s}^{2}\right)$, $\sigma_{v}{ }^{\prime}$ is effective stress, and $\sigma_{v}$ is total stress. $r_{d}$ is depth reduction factor, $\left(N_{l}\right)_{60 c s}$ is corrected standard penetration value normalized by clean sand effect (in blow/feet), $\alpha$ and $\beta$ are constants of 0.17 and 0.19 , respectively.

Numerical analysis is one of methods to investigate liquefaction potential. The numerical analysis is implemented in the framework of seismic ground response analysis. The framework of onedimensional seismic ground response analysis has been presented by several researchers, such as Mase (2017b), Mase et al. (2018b), and Likitlersuang et al. (2020). The main concept of the framework is to simulate a seismic ground motion propagating through horizontally layers (Mase et al., 2018a).

Iai et al. (1992) proposed multisprings element model to capture soil behaviour during cyclic loading. The multisprings element model was originally developed based on Ishihara et al. (1975). The multisprings element model is now integrated in a Finite element LIquefaction Program (FLIP), which is reliable to investigate soil behaviour during cyclic for soil dynamic cases, especially liquefaction. Mase et al. (2018b) mentioned that the results of seismic ground response analysis using multisprings element model is generally consistent with field observation during the Tarlay Earthquake in Northern Thailand.

This study is focused in Chiang Rai Province, Northern Thailand (Figure 1). Within last decade, this area had undergone several strong earthquake events, i.e. the $\mathrm{M}_{\mathrm{w}} 6.8$ Tarlay Earthquake in 2011 and the $M_{w}$ 6.1 Mae Lao Earthquake in 2014. Both earthquakes had also triggered unique phenomena, which was known as liquefaction (Mase et al., 2018b and Mase et al., 2020a). Site investigations data, including standard penetration test and seismic down-hole were collected.

$$
F S=\frac{\exp \left(\frac{\left(N_{1}\right)_{60 c s}}{14.1}+\left(\frac{\left(N_{1}\right)_{60 c s}}{126}\right)^{2}-\left(\frac{\left(N_{1}\right)_{60 c s}}{23.6}\right)^{3}+\left(\frac{\left(N_{1}\right)_{60 c s}}{25.4}\right)^{4}-2.8\right)}{0.65 \cdot r_{d} \cdot \frac{\sigma_{v}}{\sigma_{v}^{\prime}} \frac{A_{\max }}{g} \cdot \frac{1}{M S F} \cdot \frac{1}{K_{\sigma}}}
$$

$r_{u}=\frac{2}{\pi} \arcsin \left(\frac{1}{F S}\right)^{\frac{1}{2 \alpha \beta}}$ 


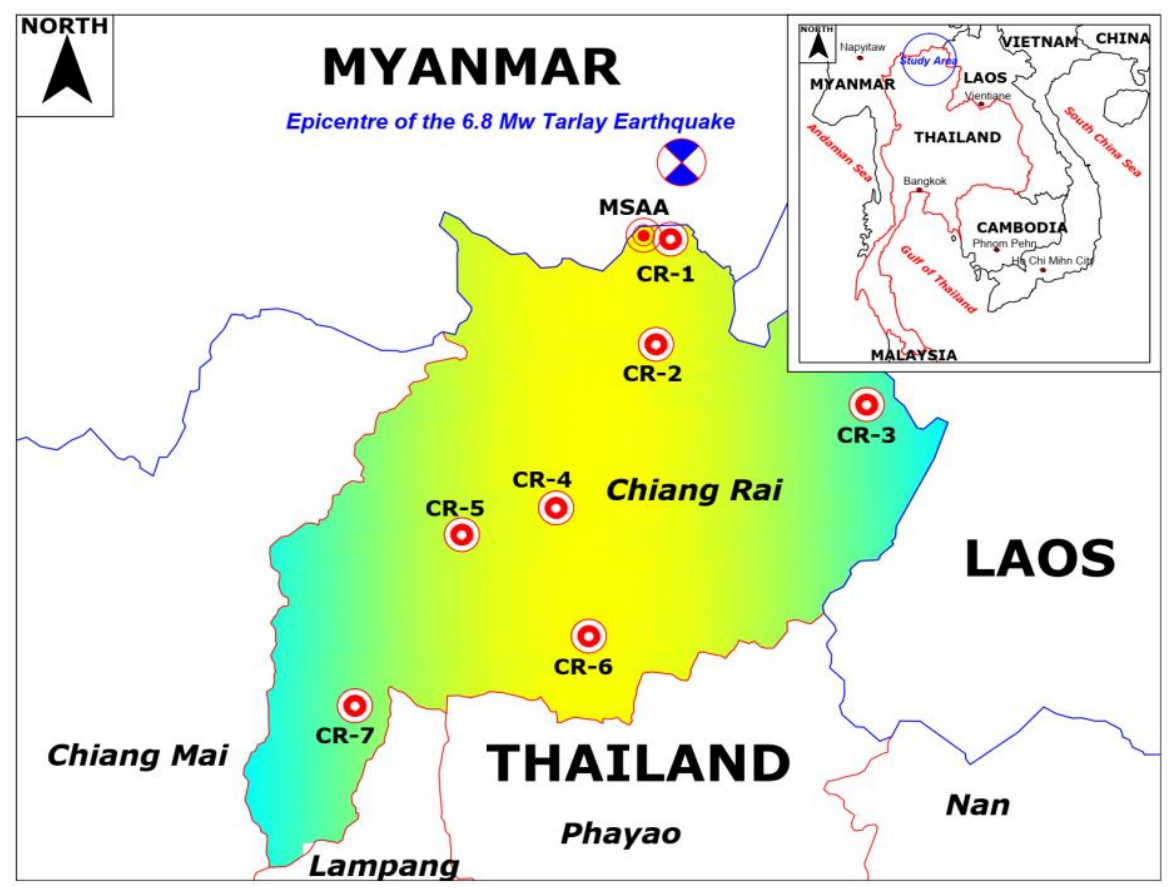

Figure 1. Location of site investigations and earthquake epicentre

Total of seven sites noted as CR-1 to CR-7 were studied. Figure 2 presents the example of site investigation data collected from the site (CR-1). CR-1 is the closest site to the Tarlay Earthquake Epicentre. During the Tarlay Earthquake, soil liquefaction had occurred in CR-1 (Mase et al., 2020b). In general, Chiang Rai subsoils (represented by CR-1) is dominated by saturated sandy soils with shallow ground water table. At shallow depth (0 to $3 \mathrm{~m})$, poor-graded sand or classified as SP based Unified Soil Classification System (USCS) is found. This layer has $\left(N_{l}\right)_{60}$ average of 6 blows/ft and $V_{s}$ of about $131 \mathrm{~m} / \mathrm{s}$. The second SP layer with $\left(N_{l}\right)_{60}$ average of 6 blows/ft and $V_{s}$ of about $131 \mathrm{~m} / \mathrm{s}$ is found at depth of 3 to 15 $\mathrm{m}$. The last sand layer classified as SP-SM and SMGM is found a depth of 15 to $32 \mathrm{~m}$. $\left(N_{l}\right)_{60}$ average of this layer is about 40 blows/ft, whereas $V_{s}$ is about $866 \mathrm{~m} / \mathrm{s}$. The time-averaged shear wave velocity up to $30 \mathrm{~m}$ depth $\left(V_{s 30}\right)$ is also calculated. $V_{s 30}$ of the investigated sites are about $379 \mathrm{~m} / \mathrm{s}$. Based on National Earthquake Hazard Reduction Provision (NEHRP, 1998) it is categorised as Site Class C. The site investigation also reveals that the engineering bedrock could be identified at depth of $15 \mathrm{~m}$. At this depth, $V_{s}$ value is more than $760 \mathrm{~m} / \mathrm{s}$. Therefore, it can be categorised as engineering bedrock surface (Adampira et al., 2015).

This study was started by collecting site investigation data in Northern Thailand. The site investigation data collected included SPT, boring $\log$, and seismic down-hole data. Seven sites were studied in this research. A ground motion of Tarlay Earthquake recorded from the closest station to the earthquake rupture was also collected from Thai Meteorological Department or TMD (2015). Afterwards, the preliminary analysis to determine the soil profile description was performed. Onedimensional seismic ground response analysis was performed in this study. Multisprings element model was employed as soil model in the analysis.

A recorded ground motion recorded at Mae Sai Seismic Station or MSAA (Figure 1) used as input motion was presented in Figure 3. The input motion was then applied at the bottom of ground surface. Since this study was aimed to observe the soil behaviour under the conservative condition, then ground motion scaling for input motion on each site, was not considered.

The input parameters were obtained from the site investigation data. Several dynamic parameters, such as damping ratio, shear modulus, etc., were derived from the soil data (Mase et al., 2019). The main results, such as excess pore water pressure ratio $\left(r_{u}\right)$, hysteresis loop $(\tau-\gamma)$, and effective stress path were presented. The ground motion parameters, such as maximum acceleration $\left(A_{\max }\right)$, maximum velocity $\left(V_{\max }\right)$, Amplification Factor $(A F)$, were collected. The empirical analysis of liquefaction was also performed to determine factor of safety $(F S)$. Furthermore, the correlation between $r_{u}$ and ground motion parameters were observed. The main goal of this study is to observe tendency of $r_{u}$ against ground motion parameters. The empirical equation of $r_{u}$ considering ground motion parameters and liquefaction susceptibility was proposed in this study. 


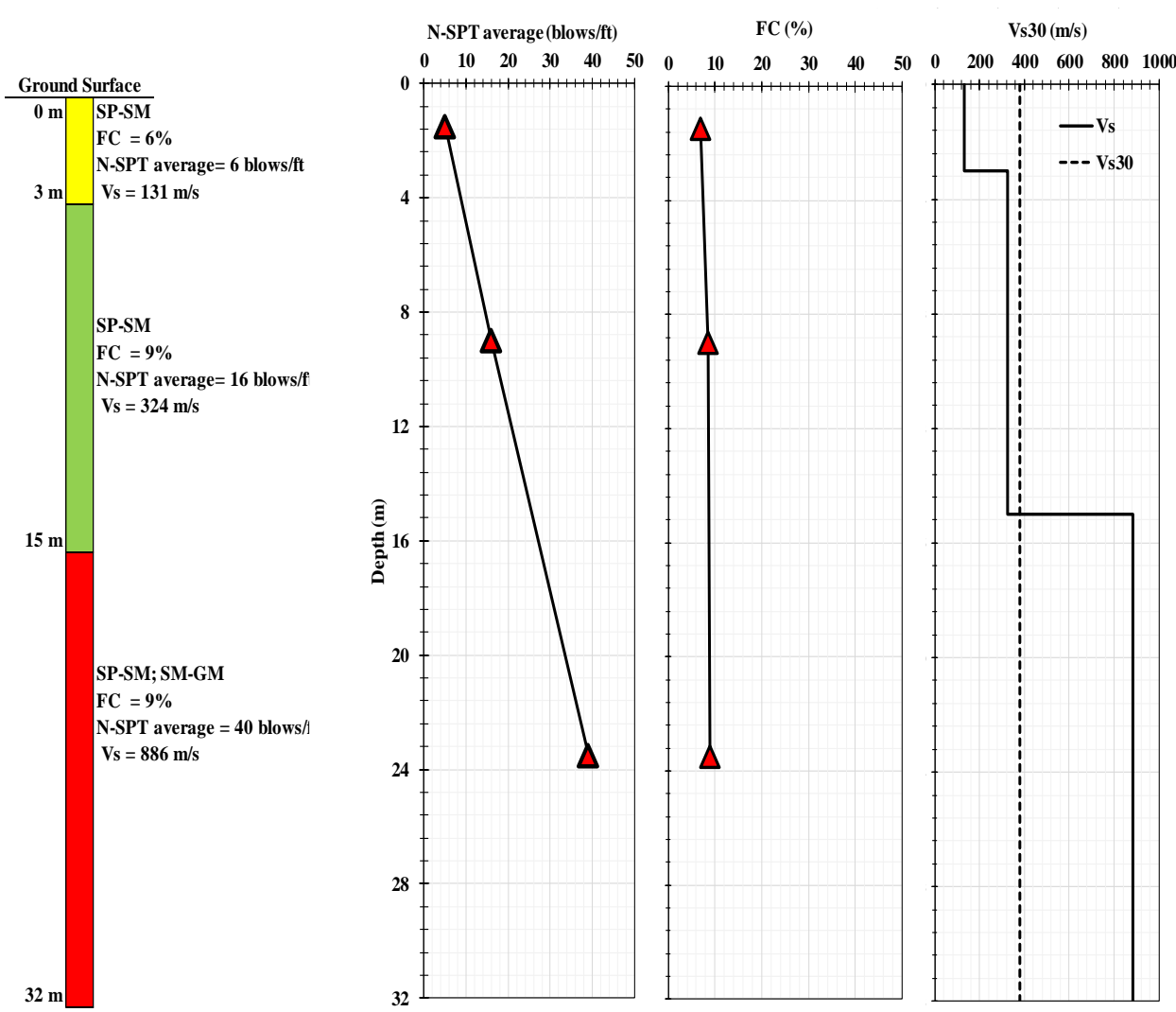

Figure 2. Example of site investigation data in Chiang Rai Province (CR-1)

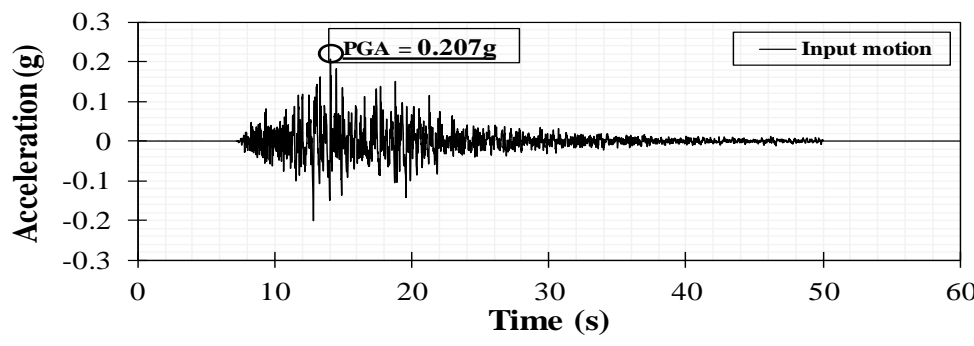

Figure 3. Recorded ground motion at MSAA Station (TMD, 2015)

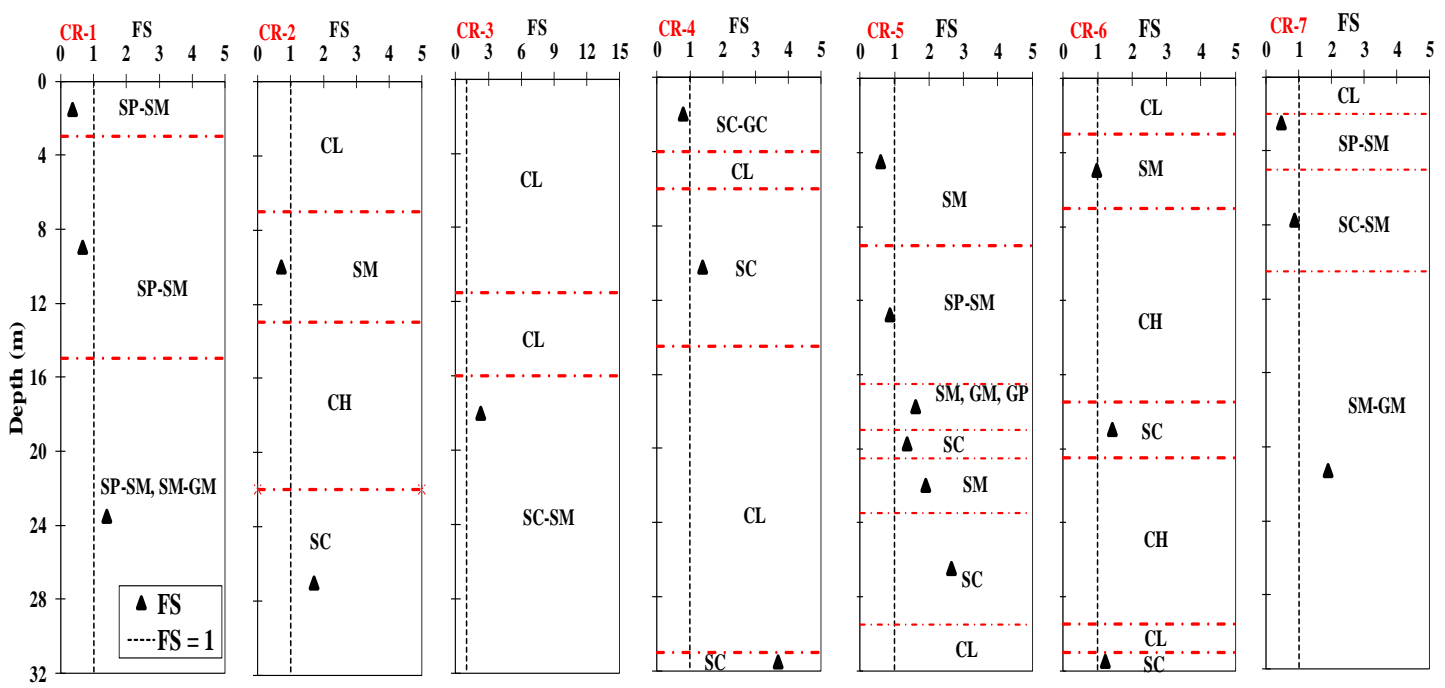

Figure 4. FS against liquefaction in the study area for CR-1 


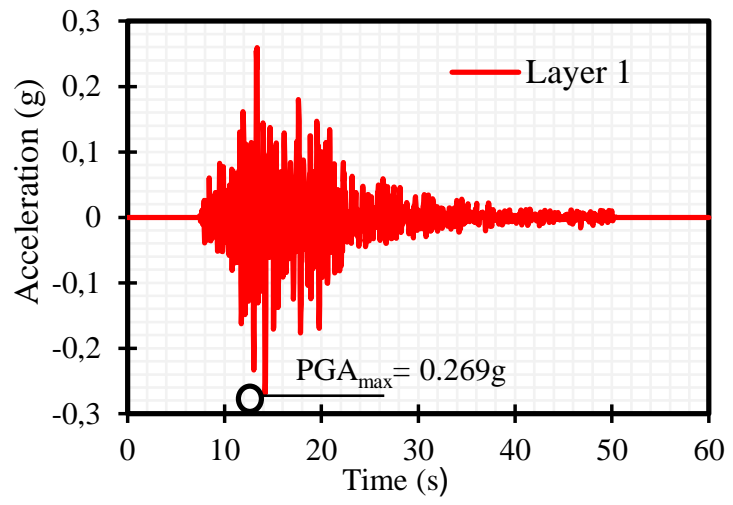

(a)

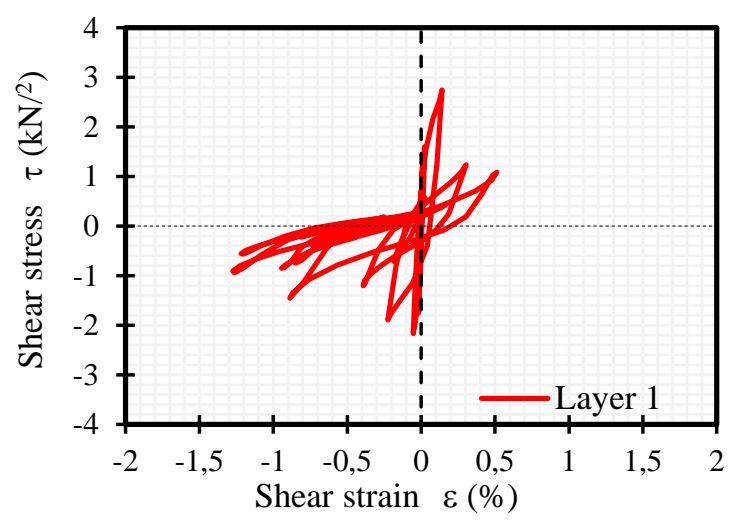

(c)

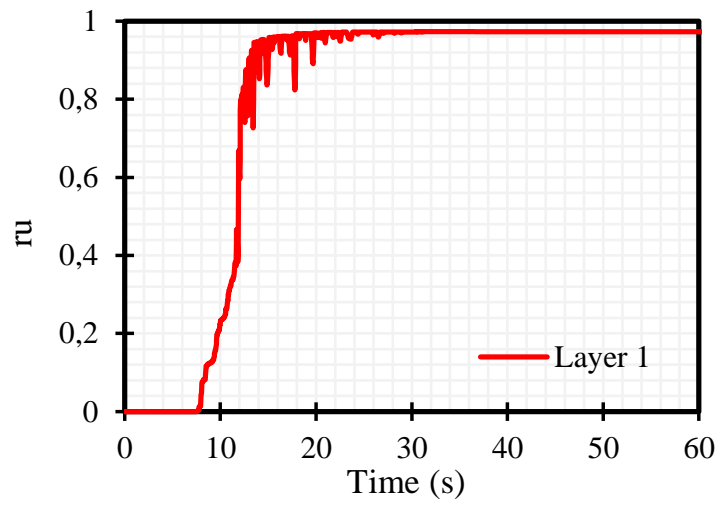

(b)

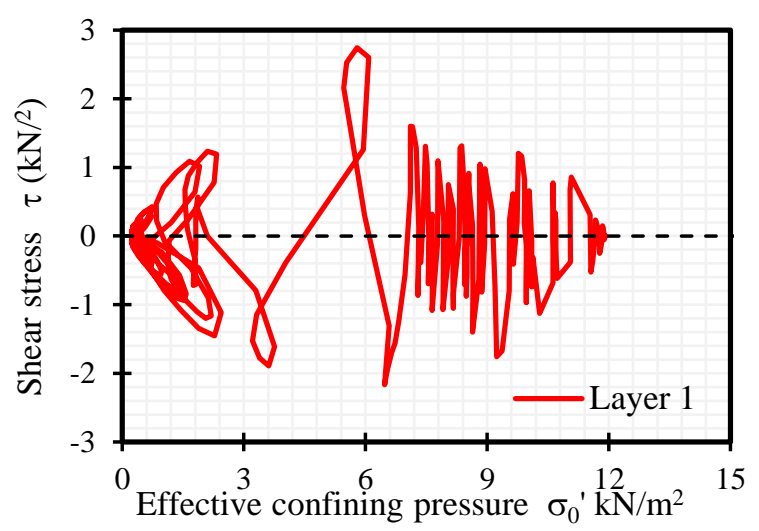

(d)

Figure 5. Soil behaviour of first sand layer in CR-1 (a) ground motion at surface (b) time history of $\mathrm{r}_{u}$ (c) hysteresis loop (d) effective stress path

\section{Results and Discussion}

\section{Liquefaction susceptibility}

FS against liquefaction in the study area is presented in Figure 4. Generally, liquefaction generally occurred at shallow depth. First and second sand layers were indicated as susceptible layers to undergo liquefaction during the Tarlay Earthquake. The results were generally consistent with several studies, such as performed by Mase et al. (2018a; 2018 b). Those previous studies were found that liquefaction could happen at shallow depth. The results showed that deeper sand layers, especially CR-1, CR-2 and CR-5 could be possible to undergo liquefaction if a stronger earthquake happen in the future. The prediction exhibited that FS was relatively close to liquefaction threshold (FS of 1). Similar recommendation had been also stated by Mase et al. (2017). It would suggest engineers to consider liquefaction in the Northern Thailand.

\section{Soil behaviours during Tarlay Earthquake}

As presented in previous section, liquefaction was generally identified on first and second sand layers. Therefore, the examples of soil behaviours resulted from one-dimensional seismic ground response analysis were only represented by liquefied layers. The example of soil behaviour of liquefied soils is presented in Figure 5, i.e. first sand layer of CR-1. In Figure 5a, the ground motion at ground surface is presented. PGA of layer 1 is about $0.269 \mathrm{~g}$. It indicates that the minimum required PGA of about 0.1g (Kramer, 1996) has been exceeded. This could be the main reason why liquefaction could happen on this layer. Time history of $r_{u}$ is presented in Figure 5b. $r_{u}$ significantly raised for first $14 \mathrm{sec}$ and constantly built up to $60 \mathrm{sec}$. Excess pore water pressure ratio $\left(r_{u}\right.$ max $)$ is about 0.98 . It indicates that liquefaction could occur during the Tarlay Earthquake. Figure 5c presents interpretation of hysteresis loop for first sand layer of CR-1. It can be seen that response of soil during the earthquake shaking was not linear. There was a reduction of shear modulus $(G)$ due to the earthquake shaking. It was indicated by flattered curves of hysteresis loop. Earthquake shaking triggered excess pore water pressure which means the increase of effective stress $\left(\sigma_{0}{ }^{\prime}\right)$. As shear modulus is influenced by effective stress. Therefore, a reduction of effective stress means a reduction of shear modulus. Figure $5 \mathrm{~d}$ presents interpretation of effective stress path during the earthquake shaking. The earthquake 
shaking could trigger the excess pore water pressure. Excess pore water pressure could decrease effective stress. In Figure 5d, the effective confining pressure was significantly decreased due to excess pore water pressure. For first sand layer of CR-1, the effective confining pressure had decrease approaching zero. It indicates that the soil shear strength disappeared and liquefaction happened.

\section{Correlations between liquefaction susceptibility and ground motion parameters}

In this study, the tendency of ground motion parameters against liquefaction potential in the study area was studied. The regression analysis was then performed. Figure 6a presents the relationship between $r_{u}$ and FS predicted by Yegian \& Vitteli
(1981). In general, the prediction resulted from the simulation is generally consistent with the measured data. Figure $6 \mathrm{~b}$ presents the relationship between $r_{u} \max$ and AF. From Figure 6b, a larger AF means a larger $r_{u}$ max. The determination coefficient of this relationship is defined by $\mathrm{R}^{2}$ of 0.5769 . Figure $6 \mathrm{c}$ presents the relationship between $V_{\max } / A_{\max }$ and AF. Based on the interpretation, a smaller AF means a larger $V_{\max } / A_{\max }$. The correlation is relatively strong. It can be observed from $\mathrm{R}^{2}$ equal to 1 . Figure $6 \mathrm{~d}$ presents the relationship between $r_{u} \max$ and $V_{\max } / A_{\max }$. Generally, tendency resulted from the relationship is that a smaller $V_{\max } / A_{\max }$ means a smaller $r_{u}$ max. The determination coefficient of this relationship $\left(\mathrm{R}^{2}\right)$ is 0.5967 . It can be concluded that generally, AF, $V_{\max } / A_{\max }$, and FS tends to have a relationship with $r_{u}$.

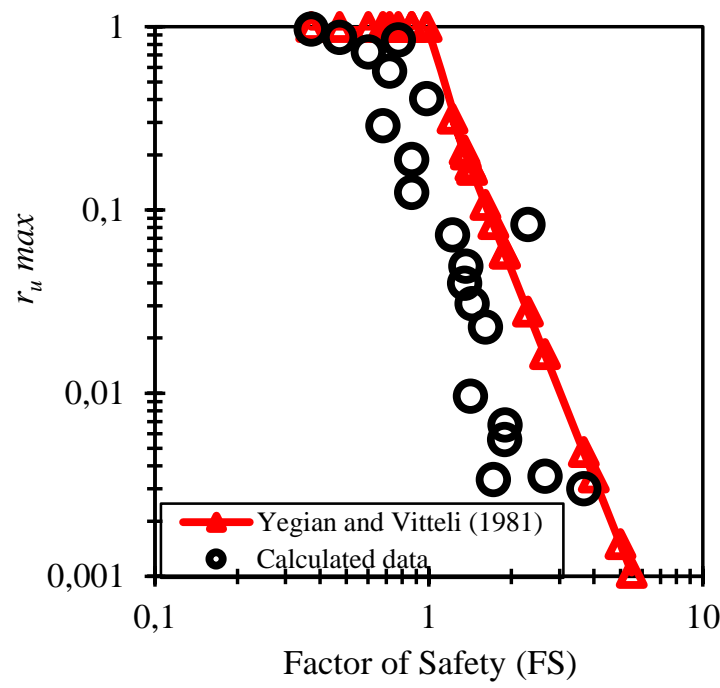

(a)

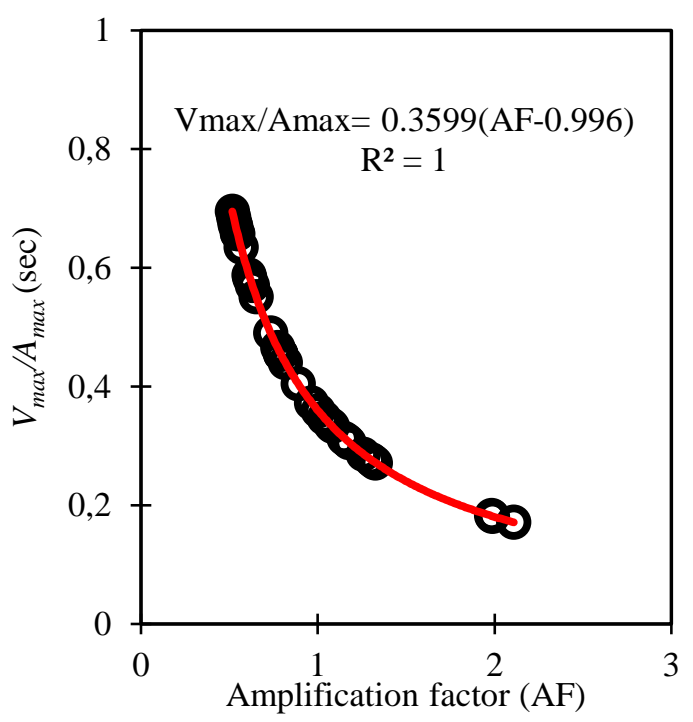

(c)

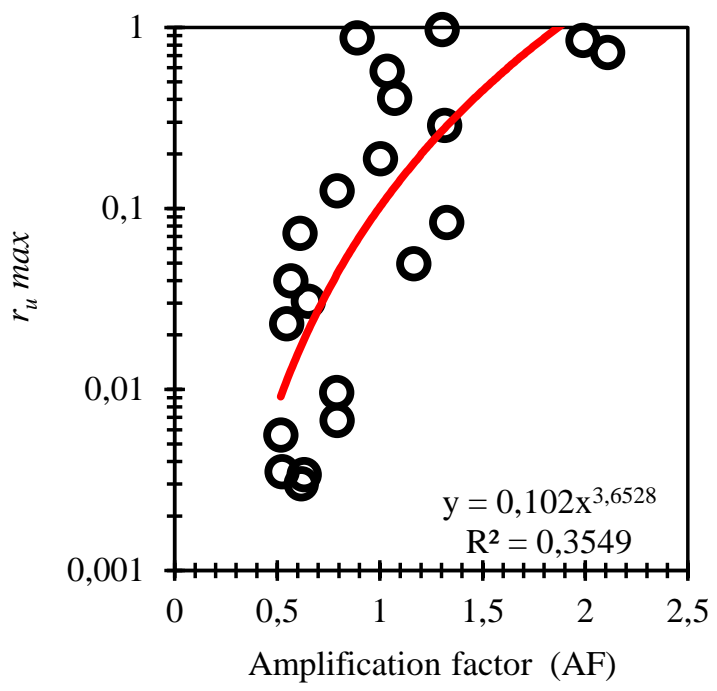

(b)

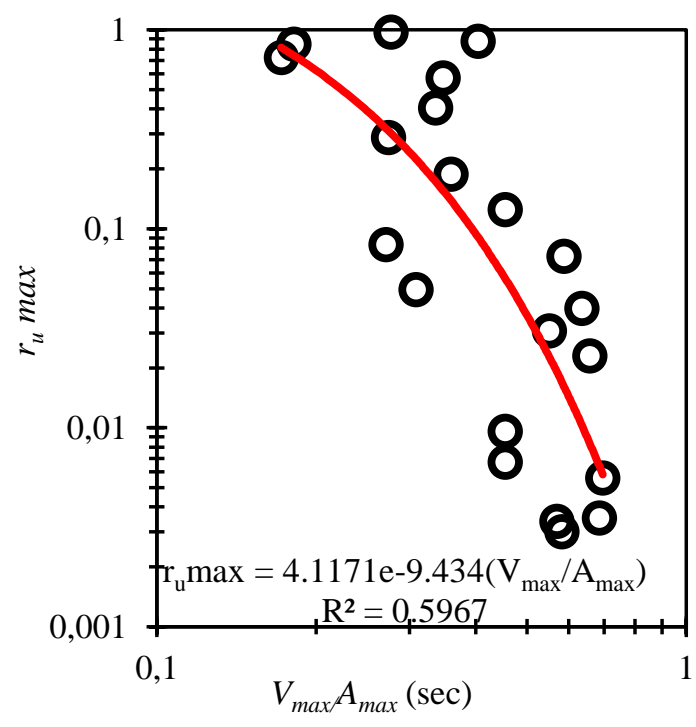

(d)

Figure 6. The relationships between ground motion parameters and liquefaction susceptibility (a) rumax vs FS (b) rumax vS AF (c) $V_{\max } / A_{\max }$ VS AF (d) $r_{u} \max$ vs $V_{\max } / A_{\max }$ 
An equation to estimate $r_{u}$, which considered the ground motion parameters and liquefaction potential, was proposed in this study. The method of multiple linear regression was performed to generate the model. Several parameters observed from Figure 6 are used to build the model.

The proposed formulation of $r_{u}$ is expressed in Equation 3. The coefficient of determination $\left(\mathrm{R}^{2}\right)$ for the proposed equation is 0.772 . The model performance (Equation 3) is presented in Figure 7.

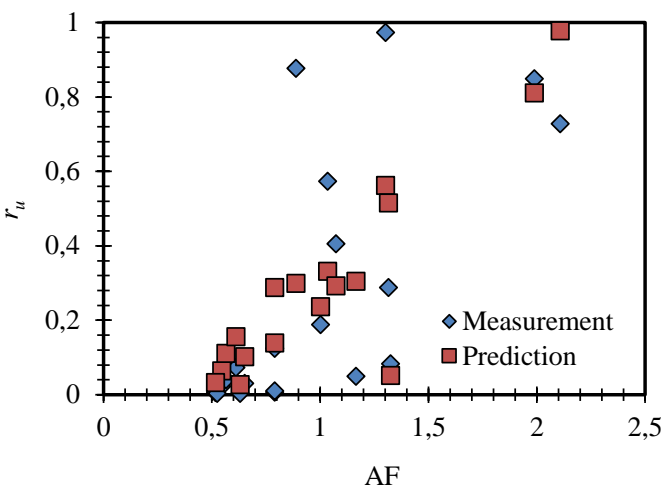

(a)

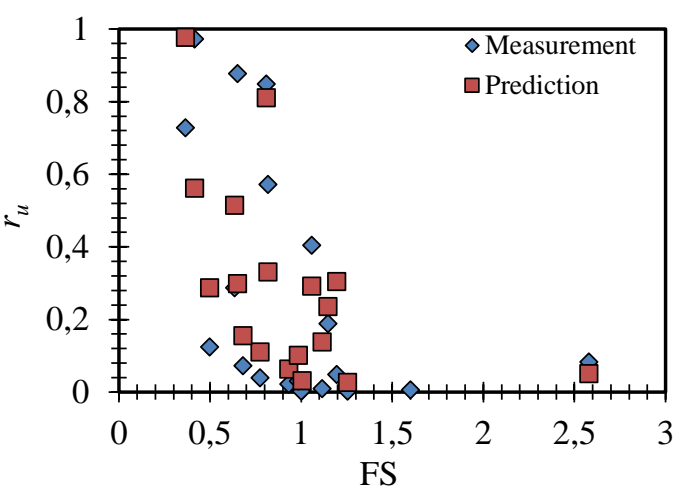

(b)

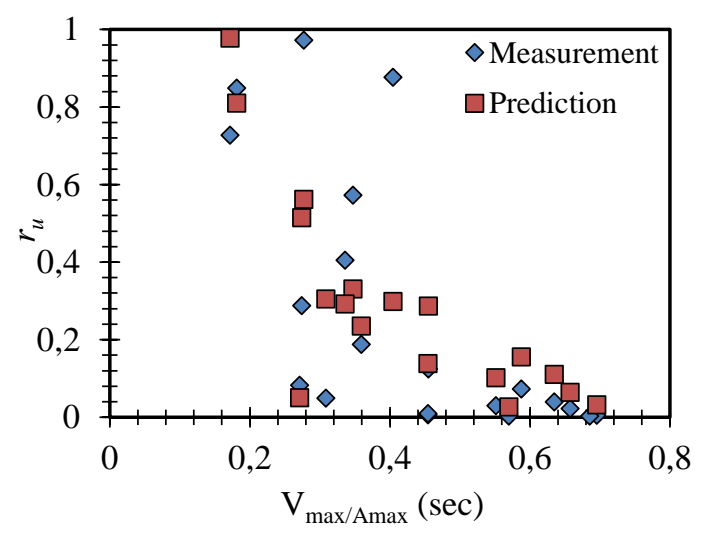

(c)

Figure 7. Estimated $r_{u}$ values from the proposed equation corresponding to (a) AF, (b) FS

(c) $V_{\max } / A_{\max }$
From the Figure, it can be observed that tendency of predicted values is generally consistent with measured values. To examine the reliability of model, the validation to the previous study of liquefaction potential during the Tarlay Earthquake performed by Mase et al. (2017; 2018b) is presented in Figure 8. As presented in Figure 8, the proposed method tends to generally overestimate $r_{u}$ value. It indicates that the proposed equation is relatively more conservative.

$$
r_{u}=0.504(A F)-0.241(F S)+0.021\left(\frac{V_{\max }}{A_{\max }}\right)
$$

\section{Conclusion}

This paper presents the study of ground motion during the strong earthquake in Northern Thailand, i.e. the 2011 Tarlay Earthquake. The analysis of ground response is performed to observe soil behavior during earthquake shaking. The model to predict liquefaction is introduced.

In general, First sand layer in Chiang Rai Province could be vulnerable to liquefaction. Ground motion parameters inclined to have correlations to liquefaction potential. The model considering the ground motion parameters and liquefaction potential was then proposed to predict $r_{u}$ during Tarlay Earthquake in 2011. The results calculated by the model were consistent with the measured $r_{u}$. The model performance in predicting $r_{u}$ from previous study was also observed. Generally, the model overestimated $r_{u}$ from the previous study. The proposed model was generally more conservative. The results of this study could contribute the development of earthquake engineering study in Northern Thailand. The research framework can be implemented to investigate the correlation between liquefaction potential and ground motion parameters.

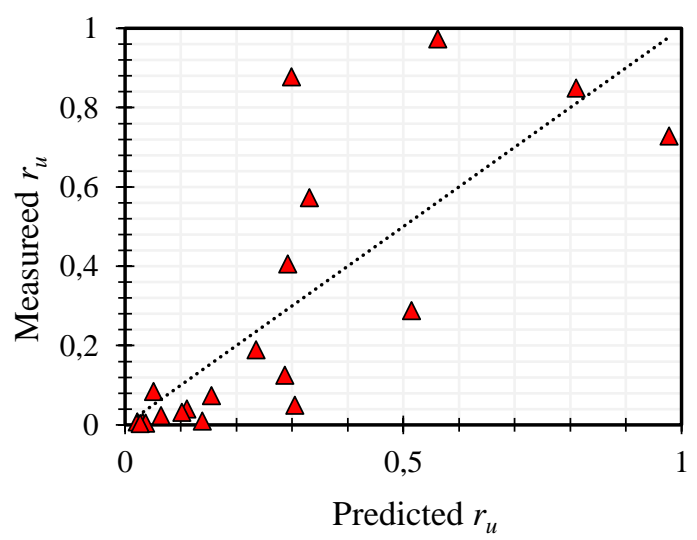

Figure 8. Performance of proposed model in predicting $r_{u}$ from the study of Mase et al. (2017) 


\section{Acknowledgement}

This research was supported by the 2019 International Collaborating Research of University of Bengkulu with No: 2183/UN30.15/LT/2019. Author would like to thank Prof Suched Likitlersuang from Chulalongkorn University and Dr. Suttisak Soralump from Kasetsart University, Thailand for the site investigation data used in this study.

\section{References}

Adampira, M., Alielahi, H., Panji, M., \& Koohsari, H. (2015). Comparison of equivalent linear and nonlinear methods in seismic analysis of liquefiable site response due to near-fault incident waves: a case study. Arabian Journal of Geosciences, 8(5), 3103-3118.

Iai, S., Matsunaga, Y., \& Kameoka, T. (1992). Strain space plasticity model for cyclic mobility. Soils and Foundations, 32(2), 1-15.

Idriss, I.M., \& Boulanger, R.W. (2006). Semiempirical procedures for evaluating liquefaction potential during earthquakes. Soil Dynamics and Earthquake Engineering, 26(2-4), 115-130.

Ishihara, K., Tatsuoka, F., \& Yasuda, S. (1975). Undrained deformation and liquefaction of sand under cyclic stresses. Soils and foundations, 15(1), 29-44.

Kramer, S.L. (1996). Geotechnical earthquake engineering. Prentice Hall, New Jersey: USA

Likitlersuang, S., Plengsiri, P., Mase, L.Z., \& Tanapalungkorn, W. (2020). Influence of spatial variability of ground on seismic response analysis: a case study of Bangkok subsoils. Bulletin of Engineering Geology and the Environment, 79(1), 35-51.

Mase, L.Z. (2017a). Liquefaction potential analysis along Coastal Area of Bengkulu Province due to the $2007 \mathrm{M}_{\mathrm{w}}$ 8.6 Bengkulu Earthquake. Journal of Engineering and Technological Sciences, 49(6), 721-736.

Mase, L.Z. (2017b). Shaking table test of soil liquefaction in Southern Yogyakarta. International Journal of Technology, 8(4), 747-760.

Mase, L.Z. (2018). Reliability study of spectral acceleration designs against earthquakes in
Bengkulu City, Indonesia. International Journal of Technology, 9(5), 910-924.

Mase, L.Z., Likitlersuang, S., \& Tobita, T. (2018a). Non-linear site response analysis of soil sites in Northern Thailand during the $\mathrm{M}_{\mathrm{w}} 6.8$ Tarlay earthquake. Engineering Journal, 22(3), 291-303.

Mase, L.Z., Likitlersuang, S., \& Tobita, T. (2018b). Analysis of seismic ground response caused during strong earthquake in Northern Thailand. Soil Dynamics and Earthquake Engineering, 114(11), 113-126.

Mase, L.Z., Likitlersuang, S., \& Tobita, T. (2019). Cyclic behaviour and liquefaction resistance of Izumio sands in Osaka, Japan. Marine Georesources and Geotechnology, 37(7), 765-774.

Mase, L.Z. (2020). Seismic hazard vulnerability of Bengkulu City, Indonesia, based on deterministic seismic hazard analysis. Geotechnical and Geological Engineering, 38, 5433-5455.

Mase, L.Z., Likitlersuang, S., \& Tobita, T. (2020b). Verification of liquefaction potential during the strong earthquake at the border of ThailandMyanmar. Journal of Earthquake Engineering, $1-28$.

Mase, L.Z., Likitlersuang, S., Tobita, T., Chaiprakaikeow, S., \& Soralump, S. (2020a). Local site investigation of liquefied soils caused by earthquake in Northern Thailand. Journal of Earthquake Engineering, 24(7), 1181-1204.

Mase, L.Z., Tobita, T., \& Likitlersuang, S. (2017). One-dimensional analysis of liquefaction potential: A case study in Chiang Rai Province, Northern Thailand, Journal of Structural Engineering and Earthquake Engineering Div JSCE, 73(4), I_135I_147.

National Earthquake Hazards Reduction Program (NEHRP). (1998). Recommended Provisions for Seismic Regulation for New Buildings and Other Structures: Part 1-Provisions and Part 2Commentary. Texas: FEMA 302.

Thai Meteorological Department (TMD). (2015). Earthquake data of March 24, 2011 earthquake. Bangkok: Thai Meteorological Department.

Yegian, M.K., \& Vitteli, B.M. (1981). Analysis of Liquefaction: Empirical Approach. In The $1^{\text {st }}$ International Conference on Recent Advance in Geotechnical Earthquake Engineering and Soil Dynamics, 173-177. 